\title{
Spiced Pineapple Ready-To-Serve Beverages
}

\author{
T. Amaravathi ${ }^{1}$, P. Vennila ${ }^{2}$, G. Hemalatha ${ }^{3}$ and P. Parimalam ${ }^{4 *}$ \\ 'Department of Family Resource Management, Home Science College and Rl, Madurai. \\ ${ }^{2}$ Department of Post Harvest Technology, Tamil Nadu Agricultural University, Coimbatore. \\ ${ }^{3}$ Department of Food Science and Nutrition, Home Science College and Rl, Madurai. \\ ${ }^{4}$ Department of Family Resource Management, Home Science College and Rl, \\ madurai, India; amarfsn@gmail.com
}

\begin{abstract}
There is a great potential for commercialization of spiced RTS beverages as natural health drinks from major and under exploited fruits not only in domestic but also at the export front. The present study portrays the nutrient content of spiced pineapple ready-to-serve beverages during fresh period. The pineapple RTS beverages were processed with extracts of ginger, green chillies, pepper, cardamom and nutmeg. The combined spices extracts such as ginger + pepper, ginger + cardamom and ginger + nutmeg were blended with pineapple juice and prepared the RTS beverages. The spiced pineapple RTS was standardized based on organoleptic evaluation. The nutrient content such as Total Soluble Solids (TSS), pH, acidity, reducing sugar, total sugar, tannin, $\beta$-carotene, ascorbic acid and non enzymatic browning were analysed. The sensory evaluation revealed that the all the beverages had good sensory properties except $B_{2}$ and $B_{3}$ beverages.
\end{abstract}

Keywords: Spiced Pineapple Ready-to-serve Beverages-nutrient Content-sensory Evaluation

\section{Introduction}

Pineapple (Ananas comosus) has long been one of the most popular of the non-citrus tropical and subtropical fruits, largely because of its attractive flavor and refreshing sugar-acid balance. Pineapple juice is largely consumed around the world, mostly as a canning industry byproduct, in the form of single strength, reconstituted or concentrated and in the blend composition to obtain new flavors in beverages and other products. Spices in foods are primarily used for their flavour and stability in storage and have natural antioxidants and antimicrobial properties apart from having carminative effect and also aid in digestion through the stimulation of appetite ${ }^{1}$. RTS beverages prepared from juices such as plum and watermelon could be increased by addition of spice extracts like ginger, black pepper, mint, cardamom and cumin ${ }^{2}$. These spice apart from their appetizing properties, also possess medicinal and therapeutic values, which have a profound effect on human health, since they affect many functional processes. The blending of juices and their spiced beverages may also improve taste, aroma, nutrition etc. Juice blending is one of the best methods to improve the nutritional quality of the juice. It can improve the vitamin and mineral content depending on the kind and quality of fruits and vegetables used3. Apart from nutritional quality improvement, blended juice can be improved in its effects among the variables, thus it cannot depict the net effects of various parameters on the reaction rate. Moreover, one could think of a new product development by blending of fruit juices with suitable spice extracts at correct proportion in order to get highly acceptable health drinks.

${ }^{*}$ Author for correspondence 


\section{Materials And Methods}

Perishable items: Fully mature, ripe pineapples (Annonas comosus), ginger and green chillies.

Non perishable items: Pepper, cardamom, nutmeg, salt, sugar and citric acid.

Bottles: Glass bottles of capacity $200 \mathrm{ml}$ and metal crown caps used for storing the prepared RTS beverages.

Selecting pineapple fruits

(Mature, sound, fresh, ripe and firm)

$\downarrow$

Removing scally portions and eyes

$\downarrow$

Extracting juice (Pulping)

$\downarrow$

Filtering juice (muslin cloth)

$\downarrow$

Preparing sugar syrup

(Sugar + citric acid + water)

$\downarrow$

Filtering sugar syrup (muslin cloth)

$\downarrow$

Cooling (syrup)

$\downarrow$

Mixing with fruit juice

$\downarrow$

Adding salt and spice extract to the fruit juice

(as per procedure)

$\downarrow$

Mixing thoroughly

$\downarrow$

Filling in bottles (head space $2 \mathrm{~cm}$ )

$\downarrow$

Crown corking

$\downarrow$

Pasteurization at $80 \mathrm{oC}$ for 30 minutes

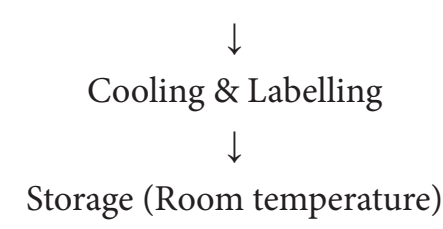

Figure 1. Flow chart for the preparation of spiced pineapple RTS beverages.

\section{Results And Discussion}

The details of the quantum of each spice extract blended with pineapple juice while processing the RTS beverages are presented in Table 1. The spiced pineapple RTS beverages $B_{1}, B_{2}, B_{3}, B_{4}, B_{5}, B_{6}, B_{7}$ and $B_{8}$ along with the control $\left(B_{0}\right)$ were selected for the study.

\subsection{Physical Characteristics of the Processed Spiced Pineapple Ready-to-serve Beverages}

The natural colour, flavour and taste of the pineapple juice was changed remarkably by the spice extracts when blended with it while processing the ready-to-serve beverages. The changes observed in the physical characteristics of the freshly prepared spiced pineapple RTS beverages are presented in Table 2. The light yellow colour of the control $\left(\mathrm{B}_{0}\right)$ had changed to yellow when ginger extract was added whereas the green chillies extract changed the colour as light cream. An attractive light yellow colour of the spiced pineapple RTS $\left(B_{3}, B_{4}\right.$ and $\left.B_{5}\right)$ were noted when pepper, cardamom and nutmeg extracts were blended to the pineapple juice. Similarly the combined spice extracts of ginger and pepper and ginger and cardamom $\left(\mathrm{B}_{6}\right.$ and $\left.\mathrm{B}_{7}\right)$ and ginger and nutmeg $\left(\mathrm{B}_{8}\right)$ had intensified the original colour (light yellow) of the pineapple juice into yellow and dark yellow respectively. The spice extracts such as green chillies, pepper and cardamom had moderately dominating their flavours in the RTS whereas ginger and nutmeg extracts showed their influence on the change of the pineapple flavour as an individual spice extract and in the combined form too.

${ }^{4}$ Spiced RTS beverage from blending mango (85\%) and pineapple (15\%) juices with aqueous spice extracts. The aqueous spice extracts consisted of curry leaf $(0.5 \%)$, cumin $(0.25 \%)$, cardamom $(0.25 \%)$, black pepper $(0.1 \%)$ and juice of ginger (0.5-2.0\%) and mint (0.4\%) along with 1-2 per cent salt (common and black salt). Results showed that the spiced RTS prepared with ginger (1\%), salt (1\%) and other spices scored the maximum score of 7.76 / 9.00.

Sindhumathi ${ }^{5}$ reported that the flavoured (ginger + cardamom) papaya blended RTS were more acceptable than the plain papaya RTS beverage. ${ }^{6}$ The spiced RTS from mango, papaya and mango-papaya blended juices. The spice extracts obtained from pepper, cardamom, cloves and cinnamon was added to the juices at the level of 10 and 15 per cent. The organoleptic qualities 
Table 1. Spice extract blended pineapple RTS beverages

\begin{tabular}{ccccccc}
\hline $\begin{array}{c}\text { Spice extract } \\
\text { blended RTS }\end{array}$ & $\begin{array}{c}\text { Pineapple } \\
\text { juice (\%) }\end{array}$ & Ginger (\%) & $\begin{array}{c}\text { Green } \\
\text { chillies (\%) }\end{array}$ & Pepper (\%) & $\begin{array}{c}\text { Cardamom } \\
(\%)\end{array}$ & $\begin{array}{c}\text { Nutmeg } \\
(\%)\end{array}$ \\
\hline $\mathrm{B}_{0}$ & 10 & - & - & - & - & - \\
$\mathrm{B}_{1}$ & 10 & 3.0 & - & - & - & - \\
$\mathrm{B}_{2}$ & 10 & - & 0.3 & - & - & - \\
$\mathrm{B}_{3}$ & 10 & - & - & 0.2 & - & - \\
$\mathrm{B}_{4}$ & 10 & - & - & - & 0.2 & - \\
$\mathrm{B}_{5}$ & 10 & - & - & - & - & 0.4 \\
$\mathrm{~B}_{6}$ & 10 & 3.0 & - & 0.2 & - & - \\
$\mathrm{B}_{7}$ & 10 & 3.0 & - & - & 0.2 & - \\
$\mathrm{B}_{8}$ & 10 & 3.0 & - & - & - & 0.3 \\
\hline
\end{tabular}

Table 2. Characteristics of the freshly prepared spiced pineapple RTS beverages

\begin{tabular}{|c|c|c|c|c|}
\hline Beverages & Colour & Flavour & Taste & $\begin{array}{l}\text { Organoleptic scores } \\
(\text { maximum 9.0) }\end{array}$ \\
\hline $\mathrm{B}_{0}$ & Light yellow & Pineapple flavour & Highly acceptable & 9.0 \\
\hline $\mathrm{B}_{1}$ & Yellow & Pineapple flavour with dominating flavour of ginger & Highly acceptable & 9.0 \\
\hline $\mathrm{B}_{2}$ & Light cream & $\begin{array}{l}\text { Pineapple flavour with moderately dominating flavour } \\
\text { of green chillies }\end{array}$ & Acceptable & 8.9 \\
\hline $\mathrm{B}_{3}$ & Light yellow & $\begin{array}{l}\text { Pineapple flavour with moderately dominating flavour } \\
\text { of pepper }\end{array}$ & Acceptable & 8.9 \\
\hline $\mathrm{B}_{4}$ & Light yellow & $\begin{array}{l}\text { Pineapple flavour with moderately dominating flavour } \\
\text { of cardamom }\end{array}$ & Highly acceptable & 9.0 \\
\hline $\mathrm{B}_{5}$ & Light yellow & Pineapple flavour with dominating flavour of nutmeg & Highly acceptable & 9.0 \\
\hline $\mathrm{B}_{6}$ & Yellow & $\begin{array}{l}\text { Pineapple flavour with dominating flavour of ginger and } \\
\text { pepper }\end{array}$ & Highly acceptable & 9.0 \\
\hline $\mathrm{B}_{7}$ & Yellow & $\begin{array}{l}\text { Pineapple flavour with dominating flavour of ginger and } \\
\text { cardamom }\end{array}$ & Highly acceptable & 9.0 \\
\hline $\mathrm{B}_{8}$ & Dark yellow & $\begin{array}{l}\text { Pineapple flavour with dominating flavour of ginger and } \\
\text { nutmeg }\end{array}$ & Highly acceptable & 9.0 \\
\hline
\end{tabular}

of the prepared RTS was found to be highly acceptable. Similarly, the spiced pineapple RTS beverages were found to be acceptable by the judges in the present study too.

\subsection{Nutrient Content of the Spiced Pineapple RTS Beverages}

The nutrient content of the freshly processed spiced pineapple RTS beverages were analyzed and presented in Table 3. It was noticed that all the RTS beverages contained the same TSS, acidity and $\mathrm{pH}$ of $15^{\circ}$ Brix, 0.250 per cent and 3.95 respectively as per FPO specification. The other nutrients of each beverage was highly influenced by the proportion of spices present in it. The reducing sugar and total sugar of the RTS beverages were ranged from 4.20 to 4.24 and 13.58 to 13.61 per cent respectively. The b-carotene content was found to be higher in $\mathrm{B}_{6}(8.06$ $\mathrm{mg} / 100 \mathrm{ml})$ followed by $B_{3}(8.04 \mathrm{mg} / 100 \mathrm{ml}), B_{2}(6.23 \mathrm{mg}$ / $100 \mathrm{ml}), \mathrm{B}_{1}, \mathrm{~B}_{7}$ and $\mathrm{B}_{8}(6.10 \mathrm{mg} / 100 \mathrm{ml})$ and $\mathrm{B}_{0}, \mathrm{~B}_{4}$ and $\mathrm{B}_{5}(6.06 \mathrm{mg} / 100 \mathrm{ml})$. The ascorbic acid content of the spiced pineapple RTS beverages varied from 3.56 to 4.10 $\mathrm{mg}$ per $100 \mathrm{ml}$. The per cent of tannic acid and non enzymatic browning found in the processed RTS were ranged between 0.154 and 0.175 and 0.128 and 0.136 (absorbance) respectively.

The prepared mixed fruit RTS from the blends of pineapple, pear and pomegranate (1:1:1). They reported that the chemical constituents of the RTS was $15^{\circ}$ Brix 
Table 3. Nutrient content of the spiced pineapple RTS beverages $(100 \mathrm{ml})$

\begin{tabular}{lccccccccc}
\hline \multirow{2}{*}{ Nutrients } & \multicolumn{10}{c}{ Beverages } \\
\cline { 2 - 10 } & $\mathrm{B}_{0}$ & $\mathrm{~B}_{1}$ & $\mathrm{~B}_{2}$ & $\mathrm{~B}_{3}$ & $\mathrm{~B}_{4}$ & $\mathrm{~B}_{5}$ & $\mathrm{~B}_{6}$ & $\mathrm{~B}_{7}$ & $\mathrm{~B}_{8}$ \\
\hline TSS ( ${ }^{\circ}$ Brix) & 15.0 & 15.0 & 15.0 & 15.0 & 15.0 & 15.0 & 15.0 & 15.0 & 15.0 \\
Acidity (g) & 0.250 & 0.250 & 0.250 & 0.250 & 0.250 & 0.250 & 0.250 & 0.250 & 0.250 \\
$\mathrm{pH}$ & 3.95 & 3.95 & 3.95 & 3.95 & 3.95 & 3.95 & 3.95 & 3.95 & 3.95 \\
Reducing sugar (g) & 4.20 & 4.21 & 4.20 & 4.20 & 4.22 & 4.23 & 4.23 & 4.24 & 4.24 \\
Total sugar (g) & 13.58 & 13.59 & 13.58 & 13.58 & 13.60 & 13.60 & 13.61 & 13.61 & 13.61 \\
$\beta$-carotene (mg) & 6.06 & 6.10 & 6.23 & 8.04 & 6.06 & 6.06 & 8.06 & 6.10 & 6.10 \\
Ascorbic acid (mg) & 3.56 & 3.59 & 4.10 & 3.56 & 3.56 & 3.56 & 3.59 & 3.59 & 3.59 \\
Tannin ( \%Tannic & 0.154 & 0.168 & 0.158 & 0.167 & 0.173 & 0.175 & 0.170 & 0.175 & 0.175 \\
acid ) & & & & & & & & & \\
Non enzymatic & 0.128 & 0.131 & 0.131 & 0.133 & 0.135 & 0.135 & 0.136 & 0.136 & 0.136 \\
browning & & & & & & & & & \\
(absorbance) & & & & & & & & & \\
\hline
\end{tabular}

TSS, 0.2 per cent acidity, $3.84 \mathrm{pH}, 4.24$ per cent reducing sugar, 14.76 per cent total sugar and $2.60 \mathrm{mg}$ of ascorbic acid per $100 \mathrm{ml}^{7}$.

The nutrient content of the whey based mango-herbal (lemon grass) beverages was analyzed by $\mathrm{Sahu}^{8}$ and reported that the fresh RTS contained TSS $15.27^{\circ}$ Brix, acidity 0.19 per cent, $\mathrm{pH} 4.38$, reducing sugar 4.57 per cent and ascorbic acid $45.0 \mathrm{mg} / 100 \mathrm{ml}$.

The chemical composition of the processed mango -pineapple spiced beverages. The prepared beverage contained TSS $10^{\circ}$ Brix, acidity 0.23 per cent, reducing sugar 4.22 per cent, total sugar 9.58 per cent, ascorbic acid (per cent retention) 1.82, total carotenoids (per cent retention) 1.23 , tannins 0.165 per cent of tannic acid and NEB (absorbance) 0.124. In the present study, similar results were observed in the prepared spiced pineapple ready-toserve beverages selected for the study ${ }^{4}$.

\subsection{Organoleptic Evaluation of Spiced Pineapple Ready-to-serve-Beverages}

Organoleptic characteristics observed in the freshly prepared spiced pineapple RTS beverages are presented in Table 4. The colour and appearance of the prepared ready-to-serve beverages were graded as like extremely to dislike very much with score values as $9-1$. The maximum score value of 9.0 were found in all the beverages except $B_{2}$ and $\mathrm{B}_{3}$ (8.9). All the beverages obtained the highest grade of 9.0 for flavour. The freshly prepared pineapple readyto-serve beverages had excellent taste (9.0) except for $B_{2}$ and $B_{3}(8.9)$. The changes noted in each quality attribute of the beverages had influenced the overall acceptability score values ( 9.0 to 8.9 ). From the data on the organoleptic evaluation of the RTS beverages it indicated that the all the beverages had overall acceptability score were 9 except $\mathrm{B}_{2}$ and $\mathrm{B}_{3}$ (8.9).

The storage period advances the overall acceptability scores decreased continuously. The tamarind RTS beverage stored at ambient temperature scored less than low temperature stored beverage. The mean overall acceptability decreased from 8.04 to $7.19^{9}$.

Slight decrease in the sensory scores were noted with spiced RTS beverages prepared from tamarind fruit juice for appearance, colour, flavour, taste and overall acceptability during the storage period. The overall acceptability scores of spiced RTS beverages were decreased from 4.0 to 3.4 at the end of the 180 days $^{10}$. Similar pattern of decrease in overall acceptability score was observed by Lakshmi ${ }^{11}$ in the flavoured tamarind RTS beverage during storage. In the present study similar picture was observed among the beverages throughout the storage period.

\section{Conclusions}

It could be possible to process spiced pineapple ready-toserve beverage by blending different spices. The colour and flavour of any processed product play an important role while tasting the same. All the processed RTS beverages were found to be highly acceptable in taste and secured the organoleptically scores as 9.0 whereas the beverages $\mathrm{B}_{2}$ and $\mathrm{B}_{3}$ were acceptable in taste and scored 8.9 only.The spiced pineapple ready-to-serve beverages 
Table 4. Organoleptic characteristics of spiced pineapple RTS beverages during storage

\begin{tabular}{lccccccccc}
\hline \multirow{2}{*}{ Quality attributes } & \multicolumn{10}{c}{ Beverages } \\
\cline { 2 - 9 } & $\mathrm{B}_{0}$ & $\mathrm{~B}_{1}$ & $\mathrm{~B}_{2}$ & $\mathrm{~B}_{3}$ & $\mathrm{~B}_{4}$ & $\mathrm{~B}_{5}$ & $\mathrm{~B}_{6}$ & $\mathrm{~B}_{7}$ & $\mathrm{~B}_{8}$ \\
\hline $\begin{array}{l}\text { Colour and } \\
\text { appearance }\end{array}$ & 9.0 & 9.0 & 8.9 & 8.9 & 9.0 & 9.0 & 9.0 & 9.0 & 9.0 \\
$\begin{array}{l}\text { Flavour } \\
\text { Taste }\end{array}$ & 9.0 & 9.0 & 9.0 & 9.0 & 9.0 & 9.0 & 9.0 & 9.0 & 9.0 \\
Overall acceptability & 9.0 & 9.0 & 8.9 & 8.9 & 9.0 & 9.0 & 9.0 & 9.0 & 9.0 \\
\hline
\end{tabular}

are having high potential for commercialization and marketability. The introduction of new types of value added and nutrient enriched spiced fruit juice based beverages might improve socio economic status of the country by enhancing the export trades.

\section{References}

1. Griffin, J. Spicing up food profits. Food Industries, 1992; 45 (11), 3-21.

2. Joshi, V. K., Chauhan, S.K., and Lal, B.B. Evaluation of enzymatically extracted plum juice and preparation of beverages. J. Food Sci. Technol., 1992; 30 (3), 208.

3. De Carvalho, J.M., Maia, G.S., and De Figueredo, R.W. Development of a blended non-alcoholic beverage composed of coconut water and cashew apple juice containing caffeine. J. Food Qual, 2007; 30, 664-681.

4. Deka, B.C., Sethi, V., and Joya Saikia. Changes in quality of mango - pineapple spiced beverage during storage. Indian J. Hort, 2005;62(1), 71-75.

5. Sindhumathi, G. (2002) M.Sc. Thesis submitted on "Standardization of blended and flavoured papaya RTS (ready-to-serve) beverages. Department of Food Science and Nutrition, Home Science College and Research Institute, Madurai.

6. Ramakrishnan, L., and Anuruby, S. Effect of selected spicemix on the quality characteristics of fruit juices. Beverage and Food World. 2004; 31(7), 55-56.

7. Saravanakumar, R., and Manimegalai, G. Storage stability of mixed fruit juice RTS beverage in different storage conditions. Beverage and Food World, 2001; 28 (2), 28.

8. Sahu, C., Patel, S., and Choudhary, P.L. Technology for manufacture of whey based mango-herbal (lemon grass) beverage. J. Food Sci. Technol., 2005; 42 (5), 421-424.

9. Kotecha, P.M., and Kadam, S.S. Preparation of ready-toserve beverage, syrup and concentrate from tamarind. Ind. Food Packer, 2003; 57(1), 76-79.

10. Kannan, S., and Banumathi, P. Studies on preparation and storage of spiced RTS from Tamarind fruit. Beverage and Food World, 2005; 32(12), 40-41.

11. Lakshmi, K., Vasanth Kumar, A.K., Jaganmohan Rao, L., and Madhava Naidu, M. Quality evaluation of flavoured RTS beverage and beverage concentrate from tamarind pulp. J. Food Sci. Technol., 2005; 42(5), 411-415. 